Please do not remove this page

RMIT

UNIVERSITY

\title{
How do consumers co-create their experiences? An exploration in the heritage sector
}

Minkiewicz, Joanna; Evans, Jody; Bridson, Kerrie

https://researchrepository.rmit.edu.au/esploro/outputs/9921859715301341/filesAndLinks?institution=61RMIT_INST\&index=null

Minkiewicz, J., Evans, J., \& Bridson, K. (2014). How do consumers co-create their experiences? An exploration in the heritage sector. Journal of Marketing Management, 30(1-2), 30-59.

https://doi.org/10.1080/0267257X.2013.800899

Document Version: Accepted Manuscript

Published Version: https://doi.org/10.1080/0267257X.2013.800899

Repository homepage: https://researchrepository.rmit.edu.au

(c) 2013 Westburn Publishers Ltd

Downloaded On 2023/04/26 14:59:34 +1000

Please do not remove this page 
Thank you for downloading this document from the RMIT Research Repository.

The RMIT Research Repository is an open access database showcasing the research outputs of RMIT University researchers.

RMIT Research Repository: http://researchbank.rmit.edu.au/

\section{Citation:}

Minkiewicz, J, Evans, J and Bridson, K 2014, 'How do consumers co-create their experiences? An exploration in the heritage sector', Journal of Marketing Management, vol. 30, no. 12, pp. 30-59.

See this record in the RMIT Research Repository at:

https://researchbank.rmit.edu.au/view/rmit:24868

Version: Accepted Manuscript

Copyright Statement: (c) 2013 Westburn Publishers Ltd

Link to Published Version:

http://dx.doi.org/10.1080/0267257X.2013.800899

\section{PLEASE DO NOT REMOVE THIS PAGE}


Title: How do consumers co-create their experiences? An exploration in the heritage sector

Joanna Minkiewicz

$\mathrm{PhD}$ candidate,

Marketing, Melbourne Business School, Carlton, Australia

Jody Evans

Senior Lecturer, PhD Program Director

Marketing, Melbourne Business School, Carlton, Australia

\section{Kerrie Bridson}

Senior Lecturer in Marketing

School of Management and Marketing, Deakin University, Burwood, Australia

Corresponding author: Joanna Minkiewicz

j.minkiewicz@mbs.edu

ph: 61393498236

\section{Author 1:}

Joanna is a doctoral candidate at Melbourne Business School, University of

Melbourne and is the recipient of the Ian Kirk Scholarship. She received her Bachelor of Arts in Psychology and German and her Bachelor of Business in Marketing (Honours) from Monash University. Her areas of interest include co-creation, service and experience marketing and branding. Joanna has published in the Journal of Services Marketing.

\section{Author 2:}

Jody Evans is Senior Lecturer at the Melbourne Business School, University of Melbourne. She received her Bachelor of Arts in English Literature and Psychology, her Bachelor of Business in Marketing (Honours) and her PhD in Marketing from Monash University. Her areas of interest include international marketing, branding, retailing and arts marketing. She has published in Journal of International Business Studies, European Journal Marketing, Journal of International Marketing, International Marketing Review and Journal of Retailing and Consumer Services, among others.

\section{Author 3:}

Kerrie Bridson is Senior Lecturer in Marketing in the School of Management and Marketing, Deakin University. She received her Bachelor of Business in Marketing (Honours) and her $\mathrm{PhD}$ in Marketing from Monash University. Her areas of interest include international marketing, branding, retailing and arts marketing. She has published in Journal of International Marketing, European Journal of Marketing, Journal of Retailing and Consumer Services, International Journal of Retail \& Distribution Management and International Journal of Information Technology and Management, among others. 


\begin{abstract}
Whilst the body of work around co-creation has grown, co-creation continues to be considered from a value perspective with key questions, such as what is actually being cocreated remaining unanswered. This article moves beyond value to experiences and explores co-creation of the consumption experience. The research examines the manifestations and antecedents of co-creation of the consumption experience from a consumer angle and presents a co-creation framework. Customer critic analysis with consumers from two exemplar heritage organisations is used to investigate co-creation. The findings illuminate three facets of co-creation: co-production, engagement and personalisation. This paper addresses a gap in S-D Logic theory, arts/heritage and broader marketing literature by distinguishing between co-creation of value and co-creation of the consumption experience and proposing a definitive conceptualisation of the latter. The proposed model progresses the co-creation discussion to an empirical level and provides a foundation for future research.
\end{abstract}

Key words: co-creation, service-dominant logic, experience, co-creation of the experience, value, heritage sector

Summary Statement of Contribution: This paper addresses a gap in S-D Logic theory, arts/heritage and broader marketing literature by distinguishing between co-creation of value and co-creation of the consumption experience and proposing a definitive conceptualisation of the latter. The proposed model progresses the co-creation discussion to an empirical level and provides a foundation for future research. 


\section{$1.0 \quad$ Introduction}

Although there is a recognised need to involve consumers in their product/service experiences (Baron \& Harris, 2010; Nambisan \& Watt, 2011), seminal scholars and practitioners consider marketing to be concerned with exchange (American Marketing Association, 2011; Bagozzi, 1975; Hunt, 1976). The purpose of exchange is to access resources that have value potential (Chandler \& Vargo, 2011). Goods-dominant logic (Normann, 2001) emphasizes the exchange of output units by multiple parties. ServiceDominant (S-D) Logic (Vargo \& Lusch, 2004) argues that the exchange and interaction processes involving operant resources of multiple parties is where value is created and emerges. Vargo and Lusch (2004) argue that consumers are value co-creators. Recent literature suggests the need to reconcile the notion of value with a focus on experiences (Gummesson, 2008; Ramaswamy, 2011). This shift is based on the premise that consumers purchase experiences, not goods or services. Researchers agree that co-creation implies a consumer who is active in the creation of their experience (Prahalad \& Ramaswamy, 2004b), but there is discord in regards to the components of co-creation. Extant research has not consistently identified the ways in which consumers co-create the experience with an organisation (Fisher \& Smith, 2011). Gronroos and Ravald (2011) suggest that, in order to better understand co-creation, it is essential to analyse consumer's roles as co-creators. Although it is acknowledged that co-creation is a process that occurs within a network of actors, the purpose of this paper is to explore co-creation of the experience from a consumer perspective.

Organisations can be classified on an experience continuum based on the number of interaction points between the organisation and the consumer (Schmenner, 1986; Verma, 2000). 'e'xperiences reside at one end of the continuum, providing limited opportunities for interaction between organisational employees and the consumer and also facilitating limited 
interaction between the consumer and the experience space. At the opposite end are "E"xperiences which provide significant opportunities for interaction between the consumer and employees. They also facilitate a greater level of interaction between consumers and the experience space, either through atmospherics or enabling reciprocal interaction with elements within the experience space. Consumer co-creation is examined in the context of the heritage sector. Organisations within the heritage sector exist at various points on the experience continuum, with some (i.e. art galleries) providing less opportunity for interaction and tailoring of the experience than others (i.e. museums) (Rolland, Patterson, \& Ward, 2010). Heritage organisations now face strong competition from retail and entertainment venues, destinations and leisure attractions. Consequently, they are driven to adopt innovative approaches to attract audiences. A more co-created experience may provide such organisations with a strong point of difference in the competition for leisure time. Heritage organisations representing different points on the experience continuum were chosen, enabling co-creation to be conceptualised in a manner that is applicable to a range of consumption experiences and to explore the drivers and inhibitors of co-creation.

\subsection{Co-creation}

Co-creation and its foundations have been considered from various perspectives (see Table 1). A review of the literature reveals a high degree of consensus at a definitional level. Co-creation involves an effort between multiple stakeholders to collaboratively co-create value/an experience. There is an evident lack of consensus, however, regarding the components of co-creation. The lack of consensus may be attributed to the lack of specificity within the conceptualisation of co-creation. Prahalad and Ramaswamy (2004b) conceptualise co-creation in terms of 4 building blocks (DART). Although this conceptualisation is comprehensive, MacLeod, Hayes and Slater (2009) argue that it is overly task-oriented 
focussing on the elements that organisations need in order for co-creation to take place rather than the way that consumers co-create.

The variety of contexts and perspectives may also have contributed to the divergence in conceptualisation. Payne, Storbacka and Frow (2008) propose a process model of cocreation, in the context of branding. Although the study presents an accurate reflection of processes that take place in the interaction between the organisation and the consumer, the actual elements of co-creation are not detailed. McColl-Kennedy et al. (2012) categorise cocreation in terms of styles in the context of the health sector. They identify some interesting activities that consumers undertake in co-creating their health care experience such as cooperating, co-learning, connecting and co-production (McColl-Kennedy et al, 2012) Although these co-creation styles are relevant to patients in the health care sector, they hold limited generalisability for service sectors outside healthcare. Prebensen and Foss (2011), in the context of tourist experiences, present a broader perspective and incorporate aspects of experiential consumption, including the use of imagination to facilitate immersion. Their findings add depth to those of Tynan, McKechnie and Chhuon (2010) who found that dialogue, complex interactions and engagement are key to co-creation of luxury brand experiences. 
Table 1: Co-creation: Definitions and conceptualisations

\begin{tabular}{|c|c|c|c|}
\hline Study & Definition/Subject of investigation & Conceptualisation & Research type/ perspective \\
\hline $\begin{array}{l}\text { Prahalad and } \\
\text { Ramaswamy } \\
(2004 b)\end{array}$ & $\begin{array}{l}\text { Co-creation of value: "the consumer and the firm are } \\
\text { intimately involved in jointly creating value that is } \\
\text { unique to the individual consumer..the interaction } \\
\text { between the consumers and firms becomes the new } \\
\text { locus of co-creation of value.." (p. x) }\end{array}$ & $\begin{array}{l}4 \text { building blocks: dialogue; access; risk } \\
\text { assessment; transparency }\end{array}$ & $\begin{array}{l}\text { Research type: Conceptual work } \\
\text { Perspective: Considers both } \\
\text { organisation and consumer but } \\
\text { their conceptualisation is } \\
\text { organisationally focussed }\end{array}$ \\
\hline $\begin{array}{l}\text { Lusch and } \\
\text { Vargo (2006) }\end{array}$ & $\begin{array}{l}\text { Co-creation of value: value can only be co-created with } \\
\text { and determined by the user in the consumption process } \\
\text { and through use or what is referred to as value in use }\end{array}$ & Co-creation of value and co-production & $\begin{array}{l}\text { Research type: Conceptual paper } \\
\text { Perspective: Considers both } \\
\text { organisation and consumer }\end{array}$ \\
\hline $\begin{array}{l}\text { Payne, } \\
\text { Storbacka and } \\
\text { Frow }(2008)\end{array}$ & $\begin{array}{l}\text { Value co-creation: involves the supplier creating } \\
\text { superior value propositions, with customers } \\
\text { determining value when a good or service is } \\
\text { consumed. }\end{array}$ & $\begin{array}{l}\text { Customer value creating processes, supplier } \\
\text { value creating processes, encounter } \\
\text { processes. }\end{array}$ & $\begin{array}{l}\text { Research type: Conceptual paper } \\
\text { Perspective: Both organisation } \\
\text { and consumer }\end{array}$ \\
\hline $\begin{array}{l}\text { McColl- } \\
\text { Kennedy, } \\
\text { Vargo, Dagger } \\
\text { and Sweeney } \\
(2012)\end{array}$ & $\begin{array}{l}\text { Customer value co-creation: "benefit realized from } \\
\text { integration of resources through activities and } \\
\text { interactions with collaborators in the customer's } \\
\text { service network" (p. 6) }\end{array}$ & $\begin{array}{l}\text { Customer value co-creation practice styles } \\
\text { (CVCPS): team manager; insular controller; } \\
\text { partnering; pragmatic adapting, passive } \\
\text { compliance }\end{array}$ & $\begin{array}{l}\text { Research type: Qualitative } \\
\text { Perspective consumer } \\
\text { perspective in the context of the } \\
\text { health sector. }\end{array}$ \\
\hline $\begin{array}{l}\text { Tynan, } \\
\text { McKechnie } \\
\text { and Chhuon } \\
(2010)\end{array}$ & $\begin{array}{l}\text { Use Prahalad and Ramaswamy's (2004b) definition of } \\
\text { co-creation }\end{array}$ & $\begin{array}{l}\text { Dialogue and complex interactions with the } \\
\text { organisation and other consumers, with } \\
\text { engagement as a direct result. }\end{array}$ & $\begin{array}{l}\text { Research type: Qualitative } \\
\text { research } \\
\text { Perspective: Both organisation } \\
\text { and consumer }\end{array}$ \\
\hline $\begin{array}{l}\text { Prebesen and } \\
\text { Foss }(2011)\end{array}$ & $\begin{array}{l}\text { Co-creation: the consumer taking an active part in } \\
\text { consuming and producing value within their } \\
\text { experience }\end{array}$ & $\begin{array}{l}\text { Use of imagination to immerse oneself in the } \\
\text { experience; interactions with objects and } \\
\text { other people; solitary activities and } \\
\text { reflection; active participation in elements of } \\
\text { the experience }\end{array}$ & $\begin{array}{l}\text { Research type: Qualitative } \\
\text { research } \\
\text { Perspective: consumer } \\
\text { perspective in the context of a } \\
\text { tourist experience }\end{array}$ \\
\hline $\begin{array}{l}\text { Ramaswamy } \\
(2011)\end{array}$ & $\begin{array}{l}\text { Co-creation: the process by which mutual value is } \\
\text { expanded together, where value to participating } \\
\text { individuals is a function of their experiences }\end{array}$ & No conceptualisation proposed & $\begin{array}{l}\text { Research type: Conceptual paper } \\
\text { Perspective: Both organisation } \\
\text { and consumer }\end{array}$ \\
\hline
\end{tabular}




\subsection{Value}

In a similar fashion to the composition of co-creation, there is also a lack of agreement about what is being co-created. Prahalad and Ramaswamy (2004b) and Vargo and Lusch (2004) originally discuss co-creation of value. However, a key principal in S-D Logic literature is the experience itself. For example: "the total co-creation experience with the network result[ing] in value" (Prahalad \& Ramaswamy, 2004b, p. 10) and "experience and perception [being] essential to value determination" (Vargo \& Lusch, 2006, p.44). This leaves uncertainty around what is actually being co-created: value or the experience.

The concept of value is a heavily contested one (Arvidsson, 2011), difficult to both define and measure (Gronroos, 2008). S-D Logic literature attempts to resolve this complexity in value literature by representing the thought around value as a progression from value-in-exchange through to value in context. This progression structure inaccurately portrays contributions to the value literature as part of a longitudinal, progressive shift. Research on value is better represented as streams of research that offer different perspectives on value. Table 2 illustrates that the marketing literature does, in fact, move back and forth between perspectives. Previous studies have summarised the progress of value literature, focussing on the diverse operationalisations, perspectives taken and the various challenges that value research presents (Gallarza, Gil-Saura \& Holbrook, 2011). Such analysis does not assist in understanding value in terms of the current research questions, specifically in relation to co-creation of value. Therefore, the discussion of value in this paper focuses on the four key value perspectives evident in literature.

Value in exchange assumes that value is inherent in either a product or service and is transferred from one party to another throughout an exchange process (Bagozzi, 1975; Hunt, 1976; Whittaker, Ledden, \& Kalafatis, 2007). Studies conceptualising value in this fashion fail to consider interaction between multiple actors, the potential for joint value creation and 
the determination of value as an outcome, rather seeing it either as inherent in the product/service or as a trade-off between what is given and what is received (Monroe, 1973, Zeithaml, 1988). In contrast, value in use considers value to be realised once it is consumed. Value-in-use pinpoints value creation as an outcome of interactions (Vargo \& Lusch, 2004; Woodall, 2003), with value being determined by the consumer based on their final evaluation of their interaction(s) and their existing preferences (Macdonald, Wilson, Martinez, \& Toosi, 2011; Sandstrom, Edvardsson, Kristensson, \& Magnusson, 2008; Woodruff, 1997). This implies that value resides within the domain of the consumer (Gronroos, 2008; Gronroos \& Ravald, 2011; Vargo \& Lusch, 2008a).

An alternative perspective on value, value-in-experience, considers value to exist in the consumer domain, but as a function of experiences (Ballantyne, Williams, \& Aitken, 2011; Bourgeon-Renault, Urbain, Petr, Le Gal-Elly \& Gombault., 2006; Ramaswamy, 2011; Ramaswamy \& Gouillart, 2010b). This aligns with our contention that it is the experience which is co-created, with value being derived from the co-created experience. Holbrook (1996, 1999, 2006) extends earlier value research (Richins, 1994; Sheth, 1991) in contending that interactions are the source of experiences and that value is derived from a consumption experience. This supports the concept of value in experience, mirroring a shift to an experience mindset (Prahalad \& Ramaswamy, 2004a, 2004b; Ramaswamy, 2010), which defines experiences as the object of value (Chen \& Chen, 2010). Bourgeon-Renault et al. (2006) support such a relational approach to value, asserting that value in arts/leisure services is inherent in the consumption experience itself.

Vargo, Maglio and Akaka (2008) suggest value in context as an alternative lens, arguing that it provides a more service system view of value. Specifically, they contend that value-in-context removes the producer-consumer distinction, emphasising the equivalence of all participants in creating value for themselves and others (Vargo et al., 2008). However, the 
essence of value-in-context is that value is uniquely and phenomenologically determined by the beneficiary. Vargo, Maglio, Akaka and He (2010) elaborate further, contending that value in context suggests that creation of value is contingent on the integration of other resources (i.e. other elements within the specific context). In line with the view that value resides in the consumer domain, this implies that value is interpreted, ultimately determined and experienced by the consumer in a given context and consumption experience. Considered in this fashion, the notion of value-in-context seems similar to that of value-in-experience. The position on value in this paper aligns with value-in-experience. We argue that value exists in the consumer domain and is derived from the experience.

It is evident that researchers have sought to examine co-creation from multiple perspectives. However, there is a distinct lack of consensus as to what is being co-created and the specific aspects of co-creation. Considering value to reside within the consumer domain, this research looks at co-creation of the experience from a consumer perspective. Gronroos $(2008 ; 2011)$ contends that the organisation and the consumer can only co-create during direct interactions. These interactions form the backbone of the consumption experience (Ramaswamy \& Gouillart, 2010a, 2010b). During such interactions, the processes of the organisation and the consumer occur simultaneously (Ballantyne, 2006; Ballantyne \& Varey, 2006) and the experience is, therefore, co-created, with value as a derived outcome. This leads to RQ1: How do consumers co-create their heritage consumption experience? It is acknowledged; however, that co-creation does not exist in a vacuum and may be influenced by a range of factors. 
Table 2: Value perspectives and conceptualisations in marketing

\begin{tabular}{|c|c|c|c|c|c|c|c|}
\hline \multicolumn{2}{|c|}{ Value-in-exchange } & \multirow[b]{2}{*}{ Study } & \multirow{2}{*}{$\begin{array}{l}\text { Value-in-use } \\
\text { Definition/Concept }\end{array}$} & \multicolumn{2}{|c|}{ Value-in-experience } & \multicolumn{2}{|c|}{ Value-in-context } \\
\hline Study & Definition/Concept & & & Study & Definition/Concept & Study & Definition/Concept \\
\hline $\begin{array}{l}\text { Bagozzi } \\
(1975)\end{array}$ & $\begin{array}{l}\text { Value is produced by a } \\
\text { party (ies) and consumed } \\
\text { by another party (ies) in a } \\
\text { process of exchange. }\end{array}$ & $\begin{array}{l}\text { Woodruff } \\
\text { (1997) }\end{array}$ & $\begin{array}{l}\text { Customer value: } \\
\text { customers perceived } \\
\text { preference for and } \\
\text { evaluation of those } \\
\text { product attributes, } \\
\text { attribute performances } \\
\text { and consequences arising } \\
\text { from use that facilitate } \\
\text { (or block) achieving the } \\
\text { customers goals and } \\
\text { purposes in use } \\
\text { situations. }\end{array}$ & $\begin{array}{l}\text { Holbrook } \\
(1996)\end{array}$ & $\begin{array}{l}\text { Customer value is an } \\
\text { interactive, relativistic } \\
\text { preference experience }\end{array}$ & $\begin{array}{l}\text { Vargo, } \\
\text { Maglio and } \\
\text { Akaka } \\
(2008)\end{array}$ & $\begin{array}{l}\text { Value in context: more } \\
\text { descriptive extension of } \\
\text { value in use, its essence } \\
\text { achieved through the } \\
\text { combination of FP } 9 \text { and } \\
\text { FP } 10 \text {. }\end{array}$ \\
\hline $\begin{array}{l}\text { Zeithaml } \\
\text { (1988) }\end{array}$ & $\begin{array}{l}\text { Consumer perceived value: } \\
\text { the customers overall } \\
\text { assessment of the utility of } \\
\text { a product based on } \\
\text { perceptions of what is } \\
\text { received and what is given }\end{array}$ & $\begin{array}{l}\text { Woodall } \\
(2003)\end{array}$ & $\begin{array}{l}\text { Value for the Customer } \\
\text { (VC): is any demand- } \\
\text { side, personal perception } \\
\text { of advantage arising out } \\
\text { of a customer's } \\
\text { association with an } \\
\text { organisation's offering; } \\
\text { Derived Value: VC } \\
\text { derived from } \\
\text { use/experience outcomes }\end{array}$ & $\begin{array}{l}\text { Holbrook } \\
(2006 ; 1999)\end{array}$ & $\begin{array}{l}\text { Value is an outcome of } \\
\text { actions and interactions } \\
\text { (i.e. experiences) and is } \\
\text { collectively produced but } \\
\text { subjectively experienced. } \\
\text { Customer value is } \\
\text { interactive (involves a } \\
\text { relationship between } \\
\text { some subject and some } \\
\text { object) and relativistic } \\
\text { (comparative, situational, } \\
\text { personal). }\end{array}$ & $\begin{array}{l}\text { Vargo, et } \\
\text { al. }(2010)\end{array}$ & $\begin{array}{l}\text { Not only is value always } \\
\text { co-created, it is also } \\
\text { contingent on the } \\
\text { integration of other } \\
\text { resources and is } \\
\text { contextually specific. }\end{array}$ \\
\hline $\begin{array}{l}\text { Sweeney and } \\
\text { Soutar (2001) }\end{array}$ & $\begin{array}{l}\text { Consumer perceived value: } \\
\text { customer's perceptions of } \\
\text { the value of a good/service }\end{array}$ & $\begin{array}{l}\text { Vargo and } \\
\text { Lusch } \\
(2004)\end{array}$ & $\begin{array}{l}\text { The enterprise can only } \\
\text { make value propositions. } \\
\text { Value emerges from the } \\
\text { interaction between the } \\
\text { firm and its customer } \\
(2004 \mathrm{a})\end{array}$ & $\begin{array}{l}\text { Prahalad and } \\
\text { Ramaswamy } \\
\text { (2004a; } \\
\text { 2004b) }\end{array}$ & $\begin{array}{l}\text { Value is now centered in } \\
\text { the experiences of } \\
\text { consumers. The total co- } \\
\text { creation experience with } \\
\text { the network results in } \\
\text { value that is more } \\
\text { personal and unique for } \\
\text { each individual (2004a). }\end{array}$ & & \\
\hline
\end{tabular}




\begin{tabular}{|c|c|c|c|c|c|c|c|}
\hline \multicolumn{2}{|c|}{ Value-in-exchange } & \multirow[b]{2}{*}{ Study } & \multirow{2}{*}{$\begin{array}{l}\text { Value-in-use } \\
\text { Definition/Concept }\end{array}$} & \multicolumn{2}{|c|}{ Value-in-experience } & \multicolumn{2}{|c|}{ Value-in-context } \\
\hline Study & Definition/Concept & & & Study & Definition/Concept & Study & Definition/Concept \\
\hline $\begin{array}{l}\text { Whittaker, } \\
\text { Ledden and } \\
\text { Kalafatis } \\
(2007)\end{array}$ & $\begin{array}{l}\text { Customer value results } \\
\text { from an analysis of costs } \\
\text { and benefits. Benefits are } \\
\text { what the customer gets and } \\
\text { the costs are what the } \\
\text { customer gives up. }\end{array}$ & $\begin{array}{l}\text { Gronroos } \\
(2008)\end{array}$ & $\begin{array}{l}\text { Value for customers } \\
\text { means that after they } \\
\text { have been assisted by a } \\
\text { self-service process } \\
\text { (cooking a meal or } \\
\text { withdrawing cash from } \\
\text { the ATM) or a full } \\
\text { service process (eating } \\
\text { out at a restaurant or } \\
\text { withdrawing cash over } \\
\text { the counter in a bank) } \\
\text { they are or feel better off } \\
\text { than before. }\end{array}$ & Flint (2006) & $\begin{array}{l}\text { Value is created by } \\
\text { customers through their } \\
\text { experiences and } \\
\text { cognitive associations } \\
\text { within and related to } \\
\text { those experiences and } \\
\text { only partially facilitated } \\
\text { by marketers. }\end{array}$ & & \\
\hline \multirow[t]{2}{*}{$\begin{array}{l}\text { Songailiene, } \\
\text { Winkhofer } \\
\text { and } \\
\text { McKechnie } \\
(2011)\end{array}$} & $\begin{array}{l}\text { Supplier perceived value } \\
\text { consists of three value } \\
\text { dimensions: financial, } \\
\text { strategic, co-creating value } \\
\text { of a customer relationship }\end{array}$ & $\begin{array}{l}\text { Sandstrom, } \\
\text { Edvardsson, } \\
\text { Kristensson } \\
\text { and } \\
\text { Magnusson } \\
(2008)\end{array}$ & $\begin{array}{l}\text { Value in use: the } \\
\text { evaluation of the service } \\
\text { experience (i.e. the } \\
\text { individual judgement } \\
\text { sum total of all of the } \\
\text { functional and emotional } \\
\text { experience outcomes ) }\end{array}$ & $\begin{array}{l}\text { Vargo } \\
(2008 \mathrm{a})\end{array}$ & $\begin{array}{l}\text { Value is always uniquely } \\
\text { and phenomenologically } \\
\text { determined by the } \\
\text { beneficiary }\end{array}$ & & \\
\hline & & $\begin{array}{l}\text { MacDonald, } \\
\text { Wilson, } \\
\text { Martinez } \\
\text { and Toosi } \\
(2011)\end{array}$ & $\begin{array}{l}\text { Value in use: a } \\
\text { customer's outcome, } \\
\text { purpose or objective that } \\
\text { is achieved through } \\
\text { service }\end{array}$ & $\begin{array}{l}\text { Helkulla, } \\
\text { Kelleher and } \\
\text { Pihlstrom } \\
(2012)\end{array}$ & $\begin{array}{l}\text { Value in experience: } \\
\text { individual customers } \\
\text { lived experiences of } \\
\text { value }\end{array}$ & & \\
\hline
\end{tabular}




\subsection{Consumer drivers and inhibitors of co-creation}

Despite the recognition of the active role of consumers in co-creating their experiences (Baron \& Harris, 2008; Baron \& Warnaby, 2011), little empirical work has been conducted around the drivers and inhibitors of a consumer's propensity to co-create. This is an important omission in the S-D Logic and co-creation literature. In order to encourage consumers to co-create and enable them to utilise their operant resources, organisations need to understand the factors that may affect the tendency of consumers to co-create their experience. In today's turbulent competitive environment and with rapid technological advances, consumers are facing ever-increasing choices of products and services and are, accordingly, driven towards experiences (Codeluppi, 2007). Coupled with being increasingly time poor, widespread access to information leaves consumers more educated, empowered and demanding of the experiences they receive. Consumers demand to be involved in personal, unique and memorable experiences (Payne, Storbacka, Frow, \& Knox, 2009). Consequently, consumers consider the hedonic aspects of their consumption experience, such as fun, fantasy, excitement and memorability of primary importance (Chen \& Chen, 2010; Tynan \& McKechnie, 2009; Hume, Sullivan Mort, Liesch, \& Winzar, 2006).

The rapid pace of social and marketplace change also implies that heritage organisations need to change the relationship that they have with consumers. The experience has not been the traditional focus of heritage organisations. For many, the focus on scholarly excellence has resulted in a strong curatorial orientation that is inward looking (Gilmore \& Rentschler, 2002; Kotler \& Kotler, 2000). As a result, the audience was limited to those who identified with the static collections and the traditional way they were presented (Kotler \& Kotler, 1998). Market led demands and government pressures on heritage organisations to develop their audience (Slater, 2010) have seen emphasis shift towards consumer centricity and the creation of a more engaging experience (Hume et al., 2006; Mencarelli, Marteux \& 
Puhl, 2010). Spaces are now designed to promote feelings of relevance and encourage consumer participation (Sweet, 2007). Despite these changes, consumers may hold culturally established preconceptions that may inhibit their ability to actively participate in the creation of a personally relevant experience (Black, 2005; Mencarelli et al., 2010).

Although some consumers prefer to keep to themselves during their heritage experience (Moore, Moore, \& Capella, 2005), most consumers come as part of a group or are exposed to the behaviour of others during their experience (Verhoef et al., 2009). Caru and Cova (2007) and Baron, Harris and Davies (1996) highlight the collective aspect of an experience where social interactions can determine the extent to which an individual is engaged in their experience. Alternatively, an abundance of others in the experience may impact a consumer's freedom to explore the space at their own pace (Hui \& Bateson, 1991; Machleit, Kellaris, \& Eroglu, 1994). It is possible that such factors may change the way a consumer co-creates their experience, some may drive consumers to co-create, whilst others may impede the process. Thus, we seek to explore the following research question: $R Q 2$. What factors drive, inhibit and change the nature of consumer co-creation in a heritage consumption experience?

\subsection{Methodology}

Harris et al. (2011) propose a data collection method that recognises consumers as active participants in the data collection process and considers service experience from a consumer perspective. The customer critic approach (CCA) focuses on doing research with, as opposed to on, consumers. CCA is ideal for the exploration of co-creation from a consumer perspective as it is aligned with the fundamentals of co-creation. It allows the research to be co-created with consumers, as consumers play an active critical role throughout the experience. Based on Pavis' Theatrical performance analysis (1985), CCA 
employs a group of consumers as co-researchers before, during and after the service experience. Their involvement before the experience takes the form of being briefed on an adapted form of the performance analysis framework. The purpose of the briefing is to enable consumers to focus on key elements of the experience with a critical mindset. During the experience, customer critics are free to share observations. As soon after the experience as possible, the customer critics take part in extensive de-briefing where they engage in a critical discourse.

Pavis' (1985) and Harris et al.'s (2011) briefing framework serves as the theoretical basis for the framework used in this research (See Appendix 1, Table 2). Our briefing framework (Appendix 1, Table 1) was based on the potential aspects of co-creation, as evident from the literature, and also incorporates a general discussion of the consumption experience. In line with Harris et al. (2011), the framework was not intended as prescriptive for participants, its aim being to enable participants to be critics during the experience, focus on key elements of co-creation and approach the experience with a critical mindset.

The CCA was conducted in two case study heritage organisations, a museum and a gallery. These two institutions were chosen as the consumption experiences exist at different points on the experience spectrum and are varied enough to cover a range of experiences. The gallery is positioned at the lower end of the experience continuum, providing limited opportunity for consumers to interact with employees, few interactive and tactile opportunities and little prospect for consumers to tailor the experience to their needs. Conversely, the museum is positioned towards the other extreme of the continuum, affording a different experience through extensive opportunities for both tactile interaction with the exhibits and personal interaction with staff, and multi-modal ways for consumers to access their experience and therefore tailor it to their needs. 
Although the briefing prior to the experience in Harris et al.'s (2011) research lasted two hours, being aware of customer critics generosity with their time and cognizant of biasing their perspective with too much detail, our briefing lasted 30 minutes. Customer critics were also provided with the option of taking the briefing framework with them on their experience. In a further modification to Harris et al.'s (2011) methodology, customer critics were provided with notepads to take notes during the experience. This was aimed at assisting recall of elements of co-creation during the post-experience discussion. Immediately following their experience, customer critics participated in a group discussion, engaging in critical discourse around the experience and how co-creation took place. Although the key aspects of co-creation, as discussed in the pre-experience briefing, were focused on, customer critics were also encouraged to discuss the experience in a holistic fashion. The critical discussion was chaired by one of the authors, with another author observing and making notes on non-verbal interaction. The group discussions at both venues were audio recorded and later transcribed.

Guided by the CCA analysis employed by Harris et al. (2011), the sense making was partly determined through critics discussing the components of co-creation, as per the briefing framework. Conceptual ordering (Strauss \& Corbin, 1998) was also conducted, whereby data was organized into discrete categories according to their properties and dimensions and then description used to clarify those categories. Employing the constant comparative method (Strauss \& Corbin, 1998), data was coded and analysed concurrently for similarities, differences, general patterns and relationships. Categories were then labelled with reference to wording used by customer critics to describe co-creation experience, previous co-creation conceptualisations and seminal literature around the themes.

In terms of sampling, customer critics were selected using purposive sampling (Patton, 2002). Participants were chosen so that manifestations of co-creation could best be 
explored, including factors with a potential influence on co-creation (i.e. previous experience at the venue or at a similar venue, age and accompaniment) (See Appendix 2). In total, 27 participants were involved in the CCA across both venues.

\subsection{Findings}

RQ1: How do consumers co-create their heritage consumption experience?

The findings suggest that customer critics actively choose to co-create their heritage consumption experiences. Their deliberate efforts are grouped under three dominant themes that reveal the dimensions of a co-created consumption experience: co-production, engagement and personalisation.

\section{Co-production.}

The findings suggest that critics actively participate in their heritage experience in numerous ways. Where they see the opportunities, both adults and families with children participate in organised tours, programs and activities. For example, Adelaide and her daughters participated in a children's art activity and this provided the girls with an opportunity to produce their own self portraits. Many critics also utilised prompts and panels in the exhibition space. This is illustrated by the following discussion:

Bob: Did you do any of the activities where you find the triangles and diamonds and things?

Amy: Yeah. I looked for those when I saw the paintings.

Kate: Did you find the diamonds? I couldn't.

Kate: I went to those [children's panels] first... It made it a little bit more fun.

Didactic panels prompted visitors to search for specific features in artwork and thereby enabled critics to play a more active role in their art consumption. Customer critics also 
actively seek tactile opportunities throughout the experience space. Whilst such opportunities were not as prevalent at the art gallery, they were a core part of the museum experience. For instance:

There's a little dome which is lit up and in there you can weigh yourself and see how many wombats you weigh, how many wombats tall you are and Lochlan got into that. But I noticed that Emily really, really liked the exhibits in there. So there was a baby wombat that she sat on and she pointed to a big wombat next to it and she said Mummy wombat, Mummy sit down. Baby giraffe, Emily stand. Mummy giraffe, Mummy stand. So through her eyes I think I got a lot more out of it (Lilly).

The experience for Lilly and her family was truly co-created because of the active component of the experience. It was evident that physically interacting with the experience space was an integral part of the experience for customer critics:

"I think these days everything is moving to technology, online, computers and I think it goes back to the element of actually physically touching and feeling. You can only learn so much from a computer and reading it in a book and reading a panel. You need to actually physically pick it up. I mean why else go to a museum?" (Alex).

Sally goes on to explain the significance of tactile opportunities in the experience: "When I was travelling through Europe, the places that I could touch, even if it's just a stone wall that's crumbled down. I know that to physically touch a stone, which is just a stone, makes it more real." Rather than being passive recipients of a staged experience, the ability to physically interact with the exhibits enabled critics to play the role of co-producer. 


\section{Engagement.}

The findings reveal that a critical component of a co-created experience was the manner in which critics engaged in their experience. Critics were engaged in their experiences through interacting with others in the form of general discussions about the exhibitions: "I thought the way they did the timeline where you could choose what period you wanted to look at was really interesting. You're reading it and talking to your partner and there are other people standing around and we started talking." (Michael). As a way of personally engaging with the experience, critics listen to stories and share personal stories with others. In the museum, customer critics were more engaged in experiences that included personal stories: "There was lots of audio as well, which was quite good because there were people's stories, which I probably preferred than just ordinary [commentary] " (Carly). In the art gallery, some critics engaged in the experience by sharing personal stores with each other:

Vicky: I chatted with a man with an interesting moustache. We were standing beside each other looking at the lederhosen picture and I said wouldn't it be nice to have a pair of lederhosen or something to that effect. Then he and I had a discussion about the cost of lederhosen. And then Jacob came over and we talked about him being from the land of lederhosen and how they're sometimes passed down for generations.

It is through the interaction with others that critics found new and different ways to connect with the objects on display.

In regards to both the gallery and museum experiences, critics reveal the need to understand the context of the objects they are seeing to help them personally relate to and fully engage in the experience. This is illustrated by this statement around the value of information panels in viewing a gallery exhibition; "[information panels] give the artwork a certain context. You're not just looking at the sculpture of Woman B, you know it's by this 
guy who lived at this time and it's in the context of the French impressionist movement. I think it gives it a bit of structure" (Bill). Cognitive immersion into the experience is also a key aspect of a co-created experience. For instance, "If you look at the lives of the artists a lot of them are 25 and they're all sort of dying in the First World War. So that really made you think about things" (Bob). Bob went on to discuss how he was a similar age to these artists and that reading the information about their lives made him reflect on his own. He was particularly moved by imagining how he would feel if he was sent to war. Customer critics are engaged in the experience through cognitively challenging content and by the use of their imaginations to relate to the experience on a personal level.

Interactive displays utilising technology, music and sounds within the experience space immerse critics, add life and a sense of relevance to the experience:

Sally: In the bugs section there was noise. It was all a bit freaky, things were moving.

Kirsten: I thought that was awesome. I loved the sound effects and actually seeing the cockroaches and then for a second I thought I felt one crawling on me. I loved it.

Typically, critics who are immersed in the experience feel in their own world, the immersion into the experience allowing them to forget reality for a short time: "I kind of liked the bubble experience. You know a removal from what's going on out there...” (Agnes).

\section{Personalisation.}

The findings reveal that, in co-creating their experience, customer critics act to personalise it. A dominant theme was that critics enter the experience space with an idea of what they want to see and do, subsequently tailoring their experience to their specific interests. For instance: “We started in Mind \& Body. We thought oh we're really interested in 
that, we'll start there and just went into everything that we could" (Sally). This 'choose your own adventure' aspect of the experience was seen by many critics as a way for them to take some control of their experience and, thereby, truly act as a co-creator. Customer critics also use maps, advice of staff members and general signage to assist them in personalising their experience. For instance, critics who come with a less concrete view of what they want to see expect guidance from staff members: "I like a tour guide to point out the things of interest. Obviously different things interest different people, but there are some of those key things that you want to be talked about and go into a bit more detail" (Alex).

In some cases, customer critics use the experience space in their own way. For instance: "We worked out that we were going to bring a picnic lunch and sit out in the back garden because it was such a beautiful place. You know if we could sneak in with a little picnic lunch and just pretend that we own the whole place" (Kate). This ability to determine, on an individual basis, how to behave in the experience space is an important aspect of personalisation. Similarly, critics chose experience spaces that allowed them to experience the exhibits in their preferred manner "I like to spend a bit more time and I like to read and concentrate. The architecture bit I loved because it was quiet in there and I could sit and I could watch and observe and learn" (Alex). Technology and interactive displays are also used by critics to tailor their experiences:

"It (the interactive panel) was awesome to be able to focus in on one particular animal out of that whole section. It was much better to be able to choose your own experience, rather than having to walk around corridors looking at every individual thing. It really catered for your own interests and what you wanted to know" (Kirsten). 
The ability to utilise technology as a personalisation tool was seen by many critics as a way for museums and galleries to deliver on visitors' expectations to enjoy a sense of freedom and choice when participating in a heritage consumption experience.

RQ2: What influences drive, inhibit and change the nature of consumer co-creation in a heritage consumption experience?

In regards to RQ2, it is evident that customer critics were driven to co-create their experience by situational factors. The ways in which they participated, engaged and personalised their experience was, at times, directly related to the emotional state that the customer critics were in. For one critic, a "lack of sleep over the last few days" (Jack) meant that he: "really liked the pieces of the museum that felt a little more serene. I really liked the areas that were kind of bright and airy and spacious and in the mood I'm in today I found some of the darker ones almost claustrophobic." For others, the fact that they were in a "nonreading kind of mood" (Sally) meant that they sought out exhibits that provided opportunities to listen to audio stories and commentary. It is apparent that the emotional state of customer critics particularly influenced the ways in which they personalised and engaged in their experience.

A second factor affecting to what extent and in what way critics co-created their experience was previous exposure to the experience. Customer critics who were familiar with the experience were more directed with regards to where they went and had specific ideas about how they were going to co-create their experience: "You have to come to the gallery and lie down in the great hall and look at the stain glass. I remember doing that as a child many, many years ago and I talked Ben into doing it. He probably thought I was crazy but, then obviously people came and they did it too" (Kate). Past experiences often influenced the 
activities that customer critics wished to participate in and lead to a high degree of coproduction.

In terms of other influencing factors, in all cases, who the critics were accompanied by and interacted with during the experience clearly determined the way that they co-created. For critics accompanied by children, the children determined what took place during the experience: "All we've done today in the last 4 hours is gone to the children's corner and the outside children's area. And that's all and they've had a great time. I've tried to get them to go elsewhere and they said no so that was our day" (Lilly). It is evident that, without children, the experience and the opportunities to co-create are different: "It was great to be able to be without kids and actually read things and spend as much time in one area as you want to without moving on" (Simon). Overall, the findings reveal that individuals accompanying the critics could directly affect the activities that critics participate in, the extent to which they are able to immerse themselves in the experience and their freedom to personalise the experience.

Another factor that affected the way critics co-created their experiences was the design of the experience space. For instance:

"In relation to the exhibition, working through those different spaces I was responding to the colours that they painted on the walls and the progression and the way in which that made me feel and the way in which I looked at the artwork in light of that."(Bill)

The modern, open experience spaces also enabled critics to engage freely in conversations with others: "In the children's section a child came up to me and showed me their creation. It was a space that just encouraged you to chat to others" (Lilly). Customer critics revealed that open, spacious designs promoted a freedom to ponder the experience, reflect and interact 
with others. It is apparent, therefore, that the design of the space had a particularly strong effect on the degree of engagement in the experience.

Interestingly, the findings reveal that a number of factors that encouraged customer critics to co-create their experience, when considered from the other end of the spectrum, acted as inhibitors to co-creation. Where previous experience was a driver of co-creation, customer critics with less exposure to a certain experience seemed overwhelmed with the amount to see and do. These critics spent time orienting themselves with the experience: "When we walked in the entrance, we didn't really know where to start from so we kind of just wandered around" (Jack). Customer critics also revealed preconceptions that may have affected their confidence and willingness to actively participate in the experience. For instance: "To be honest I didn't bring my camera because I think of museums as things that are roped off and you know keep your distance" (Michael). Familiarity with certain aspects of the experience established behavioural norms, which influenced the manner in which people co-created the experience. For example: "In my experience when visiting art galleries there's a certain culture in there and that is that you walk around, that you don't interact too much and you speak in hushed tones" (Agnes). To some degree, preconceived cultural norms inhibited some customer critics from engaging in the experience to the extent that they would have liked.

In terms of other inhibitors, critics noted the potential for other people in the experience space to negatively affect their ability to engage with the experience, immerse themselves in it and tailor it to their needs. Specifically, crowded experience spaces prevented critics from being able to access interactive parts of the exhibit: "I felt really bad because the kids were wanting to have a go and they should have priority so you're standing back and you're looking at what they are looking at, but you do want to find out your own 
information" (Marla). Crowds also impacted critics' ability to immerse themselves in a personalised experience

"The last time we were here was a Wednesday night about a week after Dali had opened and I came out feeling angry. You had to be in a line and you literally went around in this line the whole way through and it took 3 hours and you barely saw anything and you couldn't get out of your line because the gallery was full and by the end I wanted out. I was really disappointed" (Travis).

Moreover, it was evident that critics deliberately modified their behaviours, and therefore potentially the extent to which they co-created, to accommodate others in the experience: "I tend to go the opposite way. Everyone goes right and I try to go left. Everyone is packed in at the first five paintings and you can't see anything" (Wendy). Thus, whilst crowding may have inhibited customer critics' ability to co-produce and engage in their experience, it did also drive critics towards greater personalisation.

Employees were a significant factor in engaging customers in their experience and personalising the experience to their needs. Our findings also indicate that employees could act as an impediment to a co-created experience. For instance: "Our main interaction was from the security guard giving the girls dirty looks, even though they weren't doing anything. Our experience felt a lot more strained" (Daniel) In general, customer critics were sensitive to staff presence, with excessive attention being perceived unfavourably and thwarting their freedom to access the experience in their own way. Finally, where modern, open spaces promoted various modes of co-creation, the converse in terms of dimly lit, poorly designed spaces inhibited customer critics from co-creating their experiences. For instance:

Sally: It's like that wall when you first walked in and there was a plaque. You were too close to be able to see it, you had to be this far away from it to read but you needed to be that far away to see the whole wall because everything was so 
high. There was a wall behind you so you couldn't get too far back. We spent less time in some of those sections."

Poorly thought out experience spaces left critics frustrated and unable to fully engage in the experience.

\subsection{Discussion}

The results reveal that consumers actively co-create their consumption experiences through co-production, personalisation and engagement. Although always given a choice, consumers deliberately get involved in activities and utilise tactile opportunities to co-create their experience. This involvement of consumers in the production of the core experience aligns with key views of co-production (Lengnick-Hall, Claycomb, \& Inks, 2000; Lusch \& Vargo, 2006) that consumers are active participants in the organisation's work. "Work" for heritage organisations encompasses: bringing natural and social history to life (museum website) and illuminating life (gallery website). In actively participating in their experiences, consumers assist organisations in their pursuit of such goals and visions. As Etgar (2008) and White, Hede and Rentschler (2009) point out, co-production implies that consumers actively participate in the performance of one or more activities performed throughout the consumption experience. Firat et al. (1995) concur, representing the postmodern consumer as one that participates in the creation of and, indeed, defines their experience. Our findings support those of Hollenbeck, Peters and Zinkhan (2008) who, in the museum context, found that consumers who physically touched and smelt objects on exhibit had a much more lasting impression of the experience. Thus, co-production is defined as active participation in one or more activities performed throughout the consumption experience. This definition and conceptualisation of co-production focuses on the physical element of participation in the consumption experience. 
Engagement has been discussed from a process perspective that involves cognitive, emotional and behavioural aspects (Brodie et al., 2011; Hollebeek, 2011). Brodie et al. (2011) define customer engagement as "a psychological state that occurs by virtue of interactive, cocreative customer experiences with a focal agent/object. It is a multi-dimensional concept subject to a context and/or stakeholder specific expression or relevant cognitive, emotional and/or behavioural dimensions" (p. 260). In line with this definition, engagement is considered as a process with the consumer as the engagement subject and the consumption experience as the object. Consumer engagement is much more than "staging" an experience through the intentional use of services as the stage and goods as props to engage individual consumers in a way that creates a memorable event (Pine \& Gilmore, 1999; Ritzer, 2005; Schmitt, 1999). Our findings suggest that consumer engagement is a function of how cognitively and emotionally immersed one is in the experience.

Emotional immersion involves feeling a sense of personal relevance and connection to the experience. The results reveal that this is invoked through interaction, both with other consumers and staff members, where stories and memories are shared. Cognitive immersion is revealed through consumers' reflections on their experience, a desire to know more, involving questioning of their preconceptions and attitudes. We define consumer engagement as an individual's psychological state of cognitive and emotional immersion in the consumption experience. This definition largely supports that of Brodie et al. (2011), in terms of encompassing the emotional and cognitive aspects of engagement, and the behavioural component is captured in co-production.

The findings also reveal that personalisation is a critical component of co-creation. Much of the literature on personalisation focuses on the role of employees in terms of adaptive behaviours, process and outcome personalisation (Gwinner, Bitner, Brown \& Kumar, 2005; Shen \& Ball, 2009; Surprenant \& Solomon, 1987). The literature takes an 
organisational perspective of personalisation, conceptualising it in terms of how the organisation can personalise the experience for the consumer. Our findings provide an additional consumer perspective to personalisation. Consumers personalise their experience through choosing a self-directed path based on their interests, using experience spaces in their own way and through utilising technology and the assistance of employees. Fisher and Smith (2011) suggest that, in personalising products, consumers choose components of a product and put them together to make it their own. In the same way, in personalising an experience, consumers choose specific aspects of that experience that suit their particular needs and tailor their experience. Their choices may be guided by interactions with staff and by information that they have been provided with. We define personalisation as an individual's tailoring of their experience to meet their needs through self-directed customisation of the experience, interaction with service representative and technology.

The tendency of customer critics to either partake in their experience with others or interact with others within the experience space supports Verhoef et al's (2009) findings that customers often visit leisure spaces with friends or family members. Prebensen and Foss (2011) also found that consumers co-created the experience with those who shared the experience. Caru and Cova (2007) argue that immersion into an experience has a collective dimension, where social interactions can determine the extent to which an individual is immersed in their experience. Our findings support this contention and illustrate that friends, family and other consumers can influence the extent to which consumers engage with, personalise and co-produce their experience. The findings also highlight the role of employees. The significance of employees in enabling a personalised experience supports Bettencourt and Gwinner's (1996) finding that employees are a key driver of a customised service experience. The finding of employees as drivers of emotional immersion into the experience through storytelling supports Minkiewicz et al.'s (2011) contention that staff can 
make the experience come to life through the information they provide and how this is relayed.

The findings also suggest that the presence of others in the experience space can ultimately impact the opportunity for consumers to co-create. The deliberate efforts of some customer critics to avoid having others in their personal space supports the findings of Han et al. (2010). In a recreational context, consumers tried to avoid crowding by anticipating the likelihood of other individuals attending the recreational venue at the same time and adjusting their own attendance accordingly. The feelings of frustration, anger and disappointment that such crowding elicited in consumer critics in this study mirror the findings of studies conducted in a retail context (Machleit, Eroglu, \& Mantel, 2000; Machleit et al., 1994). The retail studies found a direct relationship between perceived crowding and satisfaction. Our findings suggest the source of the dissatisfaction to be the lost opportunity to co-create the experience.

Familiarity with the type of experience or previous exposure to the experience space affected the way customer critics interacted within the museum/gallery. This aligns with Black (2005) who contends that infrequent consumers value opportunities for social interaction and active participation most highly. Although this was evident in our study, our findings also suggest that infrequent visitors are the ones who are likely to be hesitant in their interactions within the experience space. This supports Caru and Cova (2007) who argue that expert consumers will be able to dive straight into the experience and get actively involved, whilst the distant feeling that may accompany novice consumers may impede their immersion.

Design of the experience space is revealed to both drive and inhibit consumers' propensity to co-create. This supports the key literature around servicescape and its effect on consumer behaviour (Bitner, 1992; Bosch, Venter, Han, \& Boshoff, 2006; Minkiewicz et al., 
2011; Wakefield \& Blodgett, 1996). Whereas much of the literature focuses on servicescape relationships with customer satisfaction, Sweet (2007) specifically argues that architecture and interior design shape museum consumer experiences. Our findings that modern, light experience spaces promote access, prompt personal reflections and emotional immersion affirm Sweet's (2007) contentions that flexible internal spaces encourage audience connection and engender new forms of engagement.

Based on the findings from the Customer Critic Analysis, it is evident that consumers co-create their experiences, as reflected in their behaviours and the processes undertaken during their experience. Figure 1 represents the emergent co-creation conceptualisation, and depicts both internal and external antecedents of co-creation of the experience in a heritage context. Our three factor model of co-creation supports and extends a number of key cocreation conceptualisations. Firstly, it provides support for Lusch and Vargo's (2006) contention of co-production as a sub-dimension of co-creation, clarifying the relationship between the two constructs. We further extend Lusch and Vargo's (2006) framework to include personalisation and engagement. In this way, similarities between our framework and that of DART (Prahalad \& Ramaswamy, 2004b), particularly in relation to interaction and dialogue, are evident. However, our framework also captures key aspects of the consumer experience such as immersion, personal relevance and tailoring of the experience. 
Figure 1: Emergent conceptual model

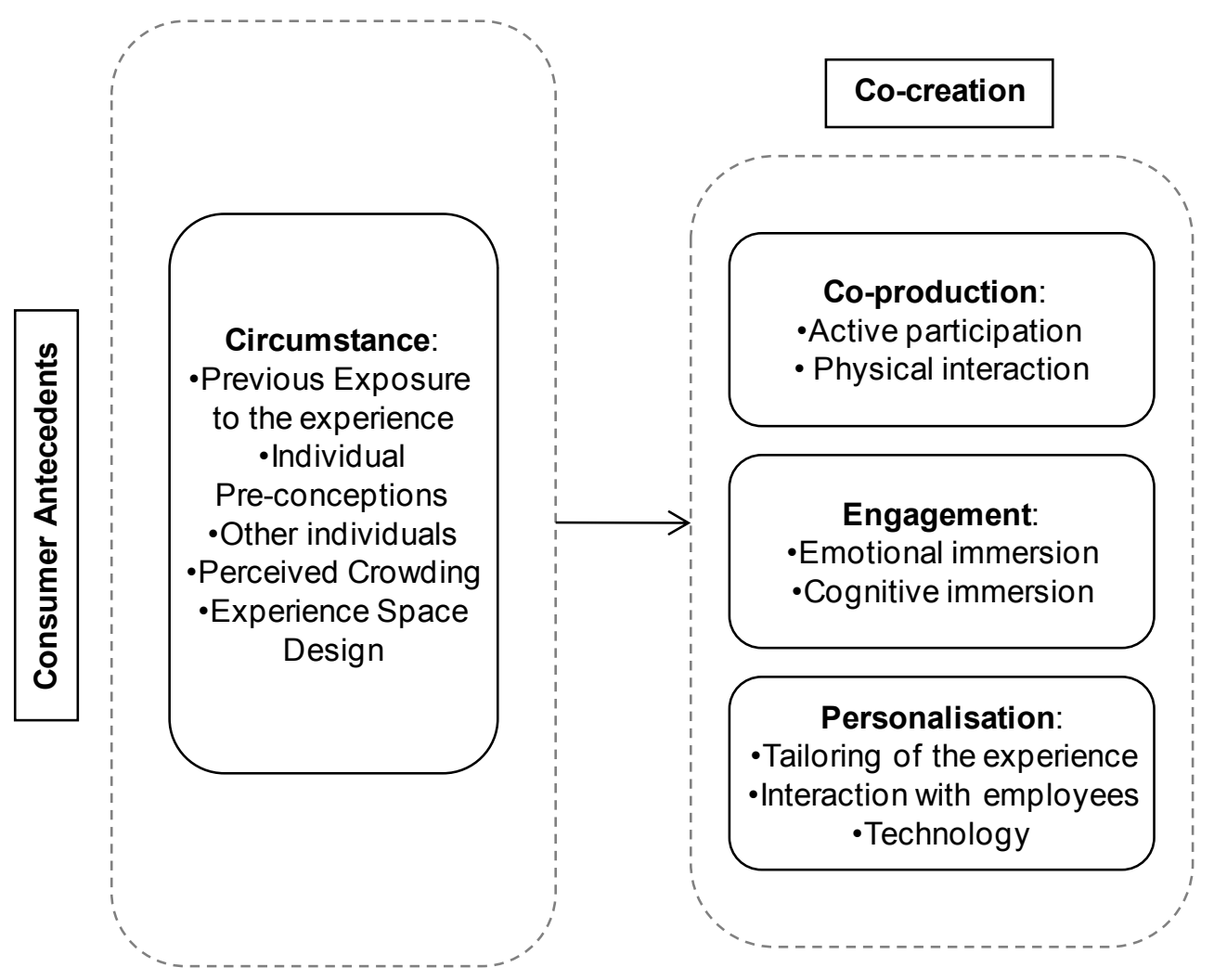

\subsection{Conclusion}

This research contributes to S-D Logic theory, arts/heritage and the broader marketing literature by demonstrating that customers actively co-create their heritage consumption experiences. Whilst S-D Logic literature regularly discusses co-creation, a consistent conceptualisation has not been forthcoming. This study addresses this gap by conceptualising co-creation from a consumer perspective and suggesting three dimensions. These dimensions are conceptualised in terms of an individual consumer's active participation in one or more activities performed in the experience (co-production); psychological state of cognitive and emotional immersion (engagement) and; tailoring of the experience to meet their needs through customisation, interaction with service representatives and technology (personalisation). Whilst most discussion of co-creation refers to co-creation of value, we distinguish between co-creation of value and co-creation of the experience, arguing that it is 
the experience that is co-created, with value as a derived outcome. This furthers the debate regarding co-creation in S-D Logic theory and extends its direct reference to services and arts/heritage literature.

To date, extensive literature around co-creation has neglected to investigate consumer drivers and inhibitors. This research addresses this gap and identifies factors that both drive and inhibit consumer co-creation. Previous exposure to the experience, other individuals and experience space design are factors facilitating a co-created experience. Interestingly, experience space design was also evident as an inhibitor of co-creation, as was perceived crowding within the experience space. Limited exposure to the experience and resultant individual preconceptions are also co-creation inhibitors. The proposed model progresses the co-creation discussion to an empirical level and moves S-D Logic towards a general marketing theory.

From a managerial perspective, this conceptualisation offers specificity in terms of how consumers co-create. The specific dimensions of a co-created experience suggest that organisations need to facilitate consumers in co-producing their experience through the provision of opportunities for active participation such as sensory and tactile tools. Heritage organisations should also facilitate emotional and cognitive engagement in the experience through creating stories, enabling customers to tell their own stories and challenging their views and knowledge base. To facilitate personalisation, heritage organisations can encourage consumers to choose their own pathway through the experience, enable them to access their experience using various modes and provide guidance and information about what is available. The findings also reveal that many aspects, such as experience space design, the presence of other consumers and the attentiveness of employees require a careful balance. Further investigation is needed into optimal levels for each of these aspects. 
The implications of these results also extend to organisations in other service sectors. In co-creating the experience with consumers, there is an opportunity for service organisations to facilitate co-production and encourage active participation of consumers in their experiences. For instance, in the restaurant sector, restaurants have begun to encourage active consumer participation in aspects of their dining experience by allowing them to design their own menus and participate in certain stages of meal preparation. Service organisations also have the opportunity to emotionally and cognitively immerse consumers in their experience in order to fully engage them and enhance the personal meaning of the experience. Within retailing, this is evident through the provision of stimulating and engaging retail environments where consumers are inspired to create and tell their own stories around their retail experience. Personalisation illuminates the critical role of frontline staff in the service context. This is evident in the banking sector where service staff fulfil specific consumer requests and personalise the banking experience to each individual consumer by finding out what transaction they most often perform and suggesting the products and services that would be best suited to their needs. In all three of these illustrative service contexts, it is evident that external factors such as perceived crowding and the design of the experience space could potentially affect the extent of consumer co-creation.

\subsection{Limitations and suggestions for future research}

This research was conducted in the context of the heritage sector. Although a seemingly specific context, experiences in the heritage sector are similar to other service based experiences, providing an opportunity for replication studies in other contexts. It is recognised that co-creation does not occur between the organisation and the consumer solely. The findings now provide an opportunity for replication studies to be conducted around cocreation with other stakeholders and in networks. This can be done in both B-C and B-B 
contexts to ascertain whether the same dimensions are evident and to identify other drivers and inhibitors of co-creation. Finally, this study provides a foundation for future co-creation research. Future empirical research could now seek to establish a reliable and valid scale of co-creation of the experience. 


\section{References}

American Marketing Association. (2011). AMA Definition of Marketing. Retrieved 5th July 2011, 2011, from http://www.marketingpower.com/Community/ARC/Pages/Additional/Definition/defa ult.aspx

Arvidsson, A. (2011). Ethics and value in customer co-production. Marketing Theory, 11(3), 261-278.

Bagozzi, R. P. (1975). Marketing as exchange. Journal of Marketing, 30(October), 32-29.

Ballantyne, D. (2006). Three perspectives in service mangement and marketing: rival logics or part of a bigger picture? Journal of Services Marketing, 20(1), 73-79.

Ballantyne, D., \& Varey, R. J. (2006). Creating value-in-use through marketing interaction: the exchange logic of relating, communicating and knowing. Marketing Theory, 6(3), 335-348.

Ballantyne, D., Williams, J., \& Aitken, R. (2011). Introduction to service-dominant logic: from propositions to practice. Industrial Marketing Management, 40(February), 179180.

Baron, S., \& Harris, K. (2008). Consumers as resource integrators. Journal of Marketing Management, 24(1-2), 113-130.

Baron, S., \& Harris, K. (2010). Toward an understanding of consumer perspectives on experiences. Journal of Services Marketing, 24(7), 518-531.

Baron, S., Harris, K., \& Davies, B. J. (1996). Oral participation in retail service delivery: a comparison of the roles of contact personnel and customers. European Journal of Marketing, 30(9), 75-90.

Baron, S., \& Warnaby, G. (2011). Individual customers' use and integration of resources: Emprical findings and organizational implications in the context of value co-creation. Industrial Marketing Management, 40, 211-218.

Bettencourt, L. A., \& Gwinner, K. (1996). Customization of the service experience: the role of the frontline employee. International Journal of Service Industry Management, $7(2), 3-20$.

Bitner, M., J.,. (1992). Servicescapes: the impact of physical surroundings on customers and employees. Journal of Marketing, 56(April), 57-71.

Black, G. (2005). The engaging museum: developing museums for visitor involvement. Abingdon, Oxon: Routledge.

Bosch, J., Venter, E., Han, Y., \& Boshoff, C. (2006). The impact of brand identity on the perceived brand image of a merged higher education institution: part one. Management Dynamics, 15(2), 10.

Bourgeon-Renault, D., Urbain, C., Petr, C., Le Gall-Elly, M., et al. (2006). An experiential approach to the consumption of value of arts and culture: the case of museums and monuments. International Journal of Arts Management, 9 (1 (Fall)), 35-47.

Brodie, R. J., Hollebeek, L., Juric, B., \& Ilic, A. (2011). Customer Engagement: conceptual domain, fundamental propositions and implications for research. Journal of Service Research, 14(3).

Caru, A., \& Cova, B. (2006). How to facilitate immersion in a consumption experience: Appropriation operations and service elements Journal of Consumer Behaviour, 5, 414.

Caru, A., \& Cova, B. (2007). Consumer Immersion in an experiential context. In A. Caru \& B. Cova (Eds.), Consuming experience (pp. 34-47). London: Routledge. 
Chandler, J. D., \& Vargo, S. L. (2011). Contextualisation and value-in-context: how context frames exchange. Marketing Theory, 11(1), 35-49.

Chen, C. F., \& Chen, F. S. (2010). Experience quality, perceived value, satisfaction, and behavioral intentions for heritage tourists. Tourism Management, 31, 29-35.

Codeluppi, V. (2007). How value-based brands create valuable experience. In A. Caru \& B. Cova (Eds.), Consuming experiences (pp. 154-166). London: Routledge.

Cova, B., \& Dalli, D. (2009). Working consumers: the next step in marketing theory? Marketing Theory, 9(3), 315-339.

Cultural Heritage National Training Organisation. (2011). What it Cultural Heritage? Retrieved 12th July, 2011, from http://www.chnto.co.uk/

Etgar, M. (2008). A descriptive model of the consumer co-production process. Journal of Academy of Marketing Science, 36, 97-108.

Fisher, D., \& Smith, S. (2011). Cocreation is chaotic: what it means for marketing when no one has control. Marketing Theory, 11(3), 325-250.

Flint, D. J. (2006). Innovation, symbolic interaction and customer valuing: thoughts stemming from a service-dominant logic of marketing. Marketing Theory, 6(3), 349362.

Gallarza, M.G, Gil-Saura, I. \& Holbrook, M. (2011). The value of value: further excursions on the meaning and role of customer value. Journal of Consumer Behaviour, 10, 179191

Gilmore, A., \& Rentschler, R. (2002). Changes in museum management: A custodial or marketing emphasis? . Journal of Management Development, 21(10), 745-760.

Gronroos, C. (2008). Service logic revisited: who creates value? And who co-creates? European Business Review, 20(4), 298-314.

Gronroos, C. (2011). A service perspective on business relationships: The value creation, interaction and marketing interface. Industrial Marketing Management, 40, 240-247.

Gronroos, C., \& Ravald, A. (2011). Service as business logic: implications for value creation and marketing. Journal of Service Management, 22(1), 5-22.

Gummesson, E. (2008). Customer centricity: reality or a wild goose chase? European Business Review, 20(4), 315-330.

Gwinner, K.P, Bitner, M.J, Brown, S.K \& Kumar, A. (2005). Service customization through employee adaptiveness. Journal of Service Research. 8(2), 131-148.

Han, Q., Dellaert, B. G. C., Van Raaij, F. W., \& Timmermans, H. J. P. (2010). Visitors strategic anticipation of crowding in scarce recreational resources. Journal of Retailing and Consumer Services, 17, 449-456.

Harris, K., Harris, R., Elliot, D., \& Baron, S. (2011). A theatrical perspective on service performance evaluation: the customer critic approach. Journal of Marketing Management, 27(5/6), 477-502.

Helkkula, A., Kelleher, C., \& Pihlstrom, M. (2012). Characterizing value as an experience: implications for service researchers and managers. Journal of Service Research(online, 10 January 2012), 1-17.

Holbrook, M. B. (2006). Consumption experience, customer value, and subjective personal introspection: an illustrative photographic essay. Journal of Business Research, 59, 714-725.

Holbrook, M. B. (Ed.). (1999). Consumer value: a framework for analysis and research. New York: Routledge.

Holbrook, M.B (1996). Customer value: a framework for analysis and research. Advances in Consumer Research, 23, 138-142

Hollebeek, L. (2011). Demysitfying customer brand engagement: exploring the loyalty nexus. Journal of Marketing Management, 27(7/8), 785-807. 
Hollenbeck, C. R., Peters, C., \& Zinkhan, G. (2008). Retail spectacles and brand meaning: insights from a brand museum case study. Journal of Retailing, 84(3), 334-353.

Hui, M. K., \& Bateson, J. E. G. (1991). Perceived control and the effects of crowding and consumer choice on the service experience. Journal of Consumer Research, 18(September), 174-184.

Hume, M., Sullivan Mort, G., Liesch, P. W., \& Winzar, H. (2006). Understanding service experience in non-profit performing arts: implications for operations and service management. Journal of Operations Management, 24, 304-324.

Hunt, S. D. (1976). The nature and scope of marketing. Journal of Marketing, 40(3), 17-28.

Johnston, R., \& Kong, X. (2011). The customer experience: a road-map for improvement. Managing Service Quality, 21(1), 5-24.

Kotler, N., \& Kotler, P. (1998). Museum Strategy and Marketing - Designing missions, Building Audiences, Generating Revenue and Resources. San Francisco, CA: JosseyBass.

Kotler, N., \& Kotler, P. (2000). Can museums be all things to all people?: Missions, goals and marketing's role. Museum management and curatorship, 18(3), 271-287.

Lengnick-Hall, C. A., Claycomb, V., \& Inks, L. (2000). From recipient to contributor: examining customer roles and experienced outcomes. European Journal of Marketing, 34(3/4), 359-383.

Lusch, R. F., \& Vargo, S. L. (2006). Service-dominant logic: reactions, reflections and refinements. Marketing Theory, 6(3), 281-288.

Macdonald, E., Wilson, H., Martinez, V., \& Toosi, A. (2011). Assessing value-in-use:a conceptual framework and exploratory study. Industrial Marketing Management, 40, 671-682.

Machleit, K. A., Eroglu, S., A, \& Mantel, S. P. (2000). Perceived retail crowding and shopping satisfaction: what modifies this relationship. Journal of Consumer Psychology, 9(1), 29-42.

Machleit, K. A., Kellaris, J. J., \& Eroglu, S., A. (1994). Human versus spatial dimensions of crowding perceptions in retail environments: a note on their measurement and effect on shopper satsifaction. Marketing Letters, 5(2), 183-194.

MacLeod, N., Hayes, D., \& Slater, A. (2009). Reading the landscape: the development of a typology of literary trails that incorporate and experiential design perspective. Journal of Hospitality Marketing and Management, 18, 154-172.

McColl-Kennedy, J., Vargo, S. L., Dagger, T., \& Sweeney, J. (2012). Health care customer value cocreation practice styles. Journal of Service Research, In Press, 1-20.

Mencarelli, R., Marteux, S., \& Puhl, M. (2010). Museums, consumers and on-site experiences. Marketing Intelligence and Planning, 28(3), 330-348.

Minkiewicz, J., Evans, J., Bridson, K., \& Mavondo, F. T. (2011). Corporate Image in the leisure services sector. Journal of Services Marketing, 25(3), 190-201.

Monroe, K.B (1973). Buyers' subjective perceptions of price. Journal of Marketing Research, 10(1), 70-80

Moore, R., Moore, M., \& Capella, M. (2005). The impact of customer-to-customer interactions in a high personal contact service. Journal of Services Marketing, 19(7), 482-491.

Museum Victoria. (2012). Corporate Information. Retrieved 14th January, 2012, from http://museumvictoria.com.au/about/corporate-information/

Nambisan, P., \& Watt, J. H. (2011). Managing customer experiences in online product communities. Journal of Business Research, 64, 889-895.

National Gallery of Victoria. (2011). Annual Report. Melbourne: National Gallery of Victoria. 
Normann, R. (2001). Reframing business: when the map changes the landscape. Chichester: Wiley.

Patton, M. (2002). Qualitative research and evaluation methods. Thousand Oaks, CA: Sage Publications.

Pavis, P. (1985). Theatre analysis: some questions and a questionnaire. New Theatre Quarterly, 1(2), 208-212.

Payne, A., Storbacka, K., \& Frow, P. (2008). Managing co-creation of value. Journal of Academy of Marketing Science, 36, 83-96.

Payne, A., Storbacka, K., Frow, P., \& Knox, S. (2009). Co-creating brands: diagnosing and designing the relationship experience'. Journal of Business Research, 62, 379-389.

Prahalad, C. K., \& Ramaswamy, V. (2004a). Co-creation experiences: the next practice in value-creation. Journal of Interactive Marketing, 18(3), 5-14.

Prahalad, C. K., \& Ramaswamy, V. (2004b). The future of competition: co-creating unique value with customers. Boston, Massachusetts: Harvard Business School Press.

Prebensen, N. K., \& Foss, L. (2011). Coping and co-creating in tourist experiences. International Journal of Tourism Research, 13, 54-67.

Ramaswamy, V. (2010). Competing through co-creation: innovation at two companies. Strategy and Leadership, 38(2), 22-29.

Ramaswamy, V. (2011). It's about human experiences...and beyond, to co-creation. Industrial Marketing Management, 40(February), 195-196.

Ramaswamy, V., \& Gouillart, F. (2010a). Building the co-creative enterprise. Harvard Business Review, October, 100-109.

Ramaswamy, V., \& Gouillart, F. (2010b). The power of co-creation. New York: Free Press.

Richins, M.L (1994). Special possessions and the expression of material values. Journal of Consumer Research, December, 522-533

Rolland, E., Patterson, R. A., \& Ward, K. F. (2010). Boundary decisions, embededness and the co-creation of value: authors' response to commentary. Canadian Journal of Administrative Sciences, 27(1), 78-80.

Sandstrom, S., Edvardsson, B., Kristensson, P., \& Magnusson, P. (2008). Value in use through service experience. Managing Service Quality, 18(2), 112-126.

Schmenner, R. W. (1986). How can businesses survive and prosper? Sloan Management Review, 27(3), 21-32.

Shen, A., \& Ball, D. (2009). Is personlization of services always a good thing? Exploring the role of technology-mediated personalization (TMP) in service relationships. Journal of Services Marketing, 23(2), 80-92.

Sherry, J. F., Kozinets, R. V., \& Borghini, S. (2007). Agents in paradise: experiential cocreation through emplacement, ritualization, community. In A. Caru \& B. Cova (Eds.), Consuming experience (pp. 17-33). London: Routhledge.

Sheth, J.N, Newman, B.I \& Gross, B.L (1991). Why we buy and what we buy: a theory of consumption values. Journal of Business Research, 22, 159-170.

Slater, A. (2010). Contemporary issues in social, arts, musuem and nonprofit marketing. International Journal of Nonprofit and Voluntary sector marketing, 15, 1-2.

Strauss, A., \& Corbin, J. (1998). Basics of Qualitative Research; Techniques and Procedures for Developing Grounded Theory. California: Sage Publications Inc.

Surprenant, C.F, \& Solomon, M.R (1987). Predictability and personalization in the service encounter. Journal of Marketing, 51 (April), 86-96.

Sweeney, J., \& Soutar, G. (2001). Consumer perceived value: the development of a multiple item scale. Journal of Retailing, 77, 203-220. 
Sweet, J. (2007). Museum architecture and visitor experience. In R. Rentschler \& A.-M. Hede (Eds.), Museum Marketing: Competing in the global marketplace (pp. 226-237). London: Butterworth-Heinemann.

Tynan, C., \& McKechnie, S. (2009). Experience marketing: a review and assessment. Journal of Marketing Management, 25(5-6), 501-517.

Tynan, C., McKechnie, S., \& Chhuon, C. (2010). Co-creating value for luxury brands. Journal of Business Research, 63, 1156-1163.

Vargo, S. L. (2008). Customer integration and value creation. Journal of Service Research, 11(2), 211-215.

Vargo, S. L., \& Lusch, R. F. (2004). Evolving to a new dominant logic for marketing. Journal of Marketing, 68(January), 1-17.

Vargo, S. L., \& Lusch, R. F. (2006). Service-dominant logic: what it is, what it is not, what it might be. In R. F. Lusch \& S. L. Vargo (Eds.), The service-dominant logic of marketing: dialog, debate and directions. Armonk, NY: M.E Sharpe.

Vargo, S. L., \& Lusch, R. F. (2008a). Service-dominant logic: continuing the evolution. Journal of Academy of Marketing Science, 36, 1-10.

Vargo, S. L., \& Lusch, R. F. (2008b). Why service? Journal of Academy of Marketing Science, 36, 25-38.

Vargo, S.L, Lusch, R. F, Akaka, M.A \& He, Y. (2010). Service-dominant logic: a review and assessment. In N. Malhotra (Ed.), Review of Marketing Research (Vol. 6, pp. 125167): Emerald Group Publishing Limited.

Vargo, S.L, Maglio, P.P \& Akaka, M.A. (2008). On value and value co-creation: a service systems and service logic perspective. European Management Journal, 26(3), 145152.

Verhoef, P. C., Lemon, K. N., Parasuraman, A., Roggeveen, A., et al. (2009). Customer experience creation: determinants, dynamics and management strategies. Journal of Retailing, 85(1), 21-41.

Verma, R. (2000). An empirical analysis of management challenges in service factories, service shops, mass service and professional services. International Journal of Service Industry Management, 11(1), 8-25.

Wakefield, K. L., \& Blodgett, J. G. (1996). The effect of servicescapes on customers' behavioural intentions in leisure settings. Journal of Services Marketing, 10(6), 45-61.

Whittaker, G., Ledden, L., \& Kalafatis, S. P. (2007). A re-examination of the relationship between value, satisfaction and intention in business services. Journal of Services Marketing, 21(5), 345-357.

Woodall, T. (2003). Conceptualising "value for the customer": an attributional, structural and dispositional analysis. Academy of Marketing Science Review, 2003(12), 1-41.

Woodruff, R. B. (1997). Customer value: the next source for competitive advantage. Journal of Academy of Marketing Science, 25(2), 139-153.

Zeithaml, V. A. (1998). Consumer preceptions of price, quality and value: a means-end model and synthesis of evidence. Journal of Marketing, 52(July), 2-22. 


\section{Appendix 1}

Table 1: Customer Critic Analysis briefing framework for the current study

Aspects for critical evaluation of experience co-creation

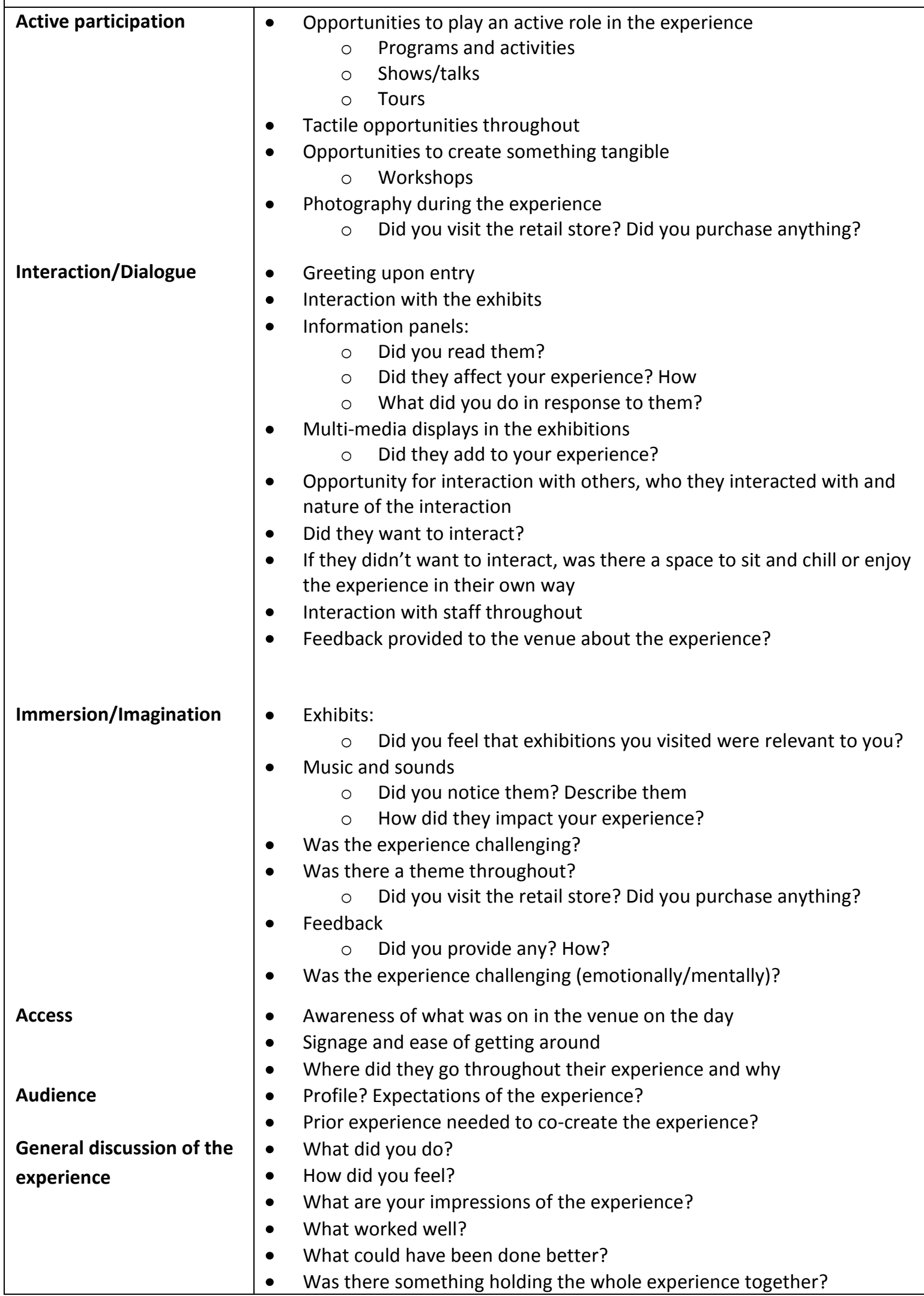


Table 2: Briefing framework from Harris et al. (2011)

\begin{tabular}{|c|c|}
\hline \multicolumn{2}{|c|}{ Some examples of components of 'mis-en-scene' (adapted from the work of Patrice Pavis, 1985)). } \\
\hline Scenography & $\begin{array}{l}\text { - Spatial relationships, Utilisation of space } \\
\text { - Decor/style/colors, Props, plants and interactions } \\
\text { - Relationship between onstage and offstage? } \\
\text { - What is shown and what is implied? } \\
\text { - Utilisation of space within the setting }\end{array}$ \\
\hline Narrative & $\begin{array}{l}\text { - The pace of the performance } \\
\text { - What story is being told - Describe the story in stages i.e. waiting for the } \\
\text { table, taking the order. Summarise it } \\
\text { To what extent does the actual storyline in performance 'fit' with } \\
\text { expectations of the performance? What are the elements of the company } \\
\text { script? Are they consistent? } \\
\text { - Where are the points of explanation? i.e when are you told what is going to } \\
\text { happen? } \\
\text { - How appropriate is the timing? } \\
\text { - Is the text in performance } \\
\text { Is the taithful to the intended story? }\end{array}$ \\
\hline Actors and Acting & $\begin{array}{l}\text { - The actors (facial expressions/costume) Acting? Exaggerated - natural, } \\
\text { appropriate? } \\
\text { - Relationship between text and acting (consistent with theme). What is said } \\
\text { and how it is said. Do they believe in what is being said? How do actors } \\
\text { act with each other? } \\
\text { - Quality of voices, accents, gestures/mime, body language } \\
\text { - Status of the actors (experienced/new) }\end{array}$ \\
\hline Audience & $\begin{array}{l}\text { - Profile? Expectations of performance } \\
\text { - What prior experience is needed to appreciate the plot? } \\
\text { - How did the audience react? To the other members of the audience/to the } \\
\text { actors and to the general performance? Level of involvement? } \\
\text { - Were there particular elements of the performance which provoke a } \\
\text { particular audience response? }\end{array}$ \\
\hline Sensory stimuli & $\begin{array}{l}\text { - Colour, shape, brightness, direction and intensity, effects of lighting } \\
\text { - Music and sound quality, smells, intensity appropriateness. Mood and } \\
\text { atmosphere } \\
\text { - Food }\end{array}$ \\
\hline $\begin{array}{l}\text { General discussion of } \\
\text { the performance }\end{array}$ & $\begin{array}{l}\text { - Coherence? What are the highs and lows? Which parts are } \\
\text { strong/weak/boring/exciting? } \\
\text { - What holds the whole experience/performance together? } \\
\text { - What didn't make sense? }\end{array}$ \\
\hline
\end{tabular}




\section{Appendix 2: CCA Participant profiles}

Table 1: CCA Participant profiles

\begin{tabular}{|c|c|c|c|}
\hline Participant & Age & Sex & Background and Characteristics \\
\hline \multicolumn{4}{|l|}{ Museum } \\
\hline Jane & Early 50’s & $\mathrm{F}$ & Husband and wife, attended with a daughter aged 9 year \\
\hline Jack & Early 50’s & M & (Florence) \\
\hline Lilly & Early 40’s & $\mathrm{F}$ & Husband and wife, attended with a daughter aged 2 (Emily) \\
\hline Joel & Early 40’s & M & $\begin{array}{l}\text { and a son aged } 6 \text { (Lochlan). Regular attendees at the } \\
\text { museum with their children. }\end{array}$ \\
\hline Sandra & Late 50’s & $\mathrm{F}$ & Husband and wife attended with their son (Andrew), whom \\
\hline Harry & Early 60’s & M & they were visiting from interstate. \\
\hline Alex & Late 20 's & M & \\
\hline Michael & Early 30’s & $\mathrm{M}$ & Young, married couple who rarely attend the museums and \\
\hline Marla & Late 20's & $\mathrm{F}$ & $\begin{array}{l}\text { galleries in their home town, being more likely to seek out } \\
\text { such experiences on holidays. }\end{array}$ \\
\hline Carly & Mid 40’s & $\mathrm{F}$ & Couple, both teachers and, as a result, usually attend places \\
\hline Simon & Early 50’s & M & $\begin{array}{l}\text { such as the museum on excursions with students. Would not } \\
\text { normally consider coming to the museum as a preferred } \\
\text { leisure activity. }\end{array}$ \\
\hline Sally & Early 30’s & $\mathrm{F}$ & Friends who have not attended the museum in several years. \\
\hline Kirsten & Early 30’s & $\mathrm{F}$ & \\
\hline Michelle & Early 30’s & $\mathrm{F}$ & Couple who are regular attendees at museums and galleries. \\
\hline Nigel & Late 30's & M & \\
\hline \multicolumn{4}{|l|}{ Gallery } \\
\hline Agnes & Late 30’s & $\mathrm{F}$ & Married couple, attended with their two daughters, aged 2 \\
\hline Daniel & Late 30’s & M & (Samantha) and 5 (Josie) for the first with their children. \\
\hline Adelaide & Late 30’s & $\mathrm{F}$ & $\begin{array}{l}\text { Mother, attended with her two daughters, aged } 7 \text { (Jillian) and } \\
9 \text { (Amy). Had not brought her daughters to the gallery } \\
\text { before. }\end{array}$ \\
\hline Kate & Mid 50’s & $\mathrm{F}$ & \multirow{2}{*}{$\begin{array}{l}\text { Mother, attended the gallery with her son (Bob). It had been } \\
\text { quite some time since both had attended the gallery. }\end{array}$} \\
\hline Bob & Late 30 's & M & \\
\hline Vicky & Mid 30’s & $\mathrm{F}$ & \multirow{2}{*}{$\begin{array}{l}\text { Young, married couple who attended for the first time } \\
\text { together. }\end{array}$} \\
\hline Jacob & Mid 30's & M & \\
\hline Travis & Mid 30’s & $\mathrm{M}$ & \multirow{4}{*}{$\begin{array}{l}\text { Friends who attend the gallery fairly regularly with other } \\
\text { social networks, as part of corporate functions and together. }\end{array}$} \\
\hline Charlie & Mid 30’s & M & \\
\hline Bill & Late 20 's & M & \\
\hline Tally & Late 20's & $\mathrm{F}$ & \\
\hline Wendy & Mid 40’s & $\mathrm{F}$ & $\begin{array}{l}\text { Individual, attended alone and regular attendee to museums } \\
\text { and galleries. }\end{array}$ \\
\hline
\end{tabular}

